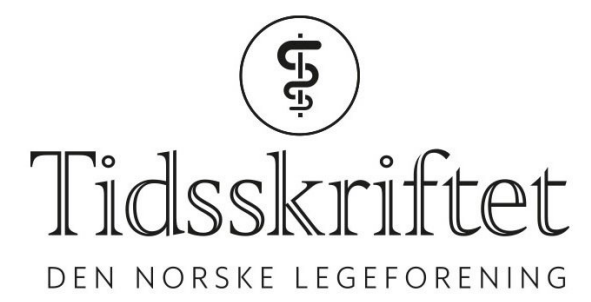

\title{
Å være fastlege i distrikt går på helsa løs
}

DEBATT

\section{THERESE RENAA}

E-post: thereserenaa@gmail.com

Therese Renaa er spesialist i allmennmedisin og jobber som kommuneoverlege og fastlege i Sel. Forfatteren har fylt ut ICMJE-skjemaet og har ingen interessekonflikter.

Utenom de store byene er bemanningen av legevaktene avhengig av omfattende unntak fra arbeidsmiljøloven. Det fører til uforsvarlig arbeidstid for legene.

Alle fastleger har en krevende jobb og jobber lange dager. Mer enn 50 timers arbeidsuke er vanlig for de fleste (1). Fastlegene er også pålagt beredskap (2). I større byer er daglegevakt ofte organisert utenom fastlegekontorene, men i små og mellomstore kommuner håndterer fastlegene akutte hendelser innimellom ordinære konsultasjoner på dagtid. Ambulansen kommer innom med pasienter for vurdering og stabilisering før transport til sykehuset. Fastlegene rykker ut fra kontoret til ulykker, hjertestans og annen akutt sykdom.

Kveld, natt og helg må det også være akuttmedisinsk beredskap i kommunen. 128 timer i uken skal dekkes av legevakt. Når fastlegekontoret stenger, fortsetter legene å jobbe. I en liten kommune med få fastleger blir vaktbelastningen deretter. Er det én lege til stede i kommunen, har denne alltid vakt. Er det to leger, slipper de unna med vakt annethvert døgn, men jobber sannsynligvis fortsatt minst 34 timer i strekk for å betjene fastlegekontoret på dagtid. Er det tre leger i kommunen, er det kanskje til og med mulig å få en frihelg av og til, i hvert fall hvis legen som har vakt, holder ut hele helga. Det er ikke uvanlig å gå på jobb fredag morgen og jobbe frem til mandag ettermiddag 80 timer senere. Ferieavvikling, kurs eller sykdom gjør det vanskelig å få kabalen til å gå opp, men i alle år har legene tatt ansvar og løst oppgaven sammen. Arbeidsmiljøloven §1o setter klare grenser for total arbeidstid, nattarbeid, sammenhengende arbeidsperioder og krav til hviletid (3). Forholdene for fastleger i distriktet sprenger alle lovens grenser.

En liten setning i særavtalen (SFS 2305) mellom Legeforeningen og KS gir rom for unntakene fra arbeidsmiljøloven (4). Det er uenighet om den setningen som nå har ført oss ut i streik.

\section{Påvirker hele livet}

Hva vil det si å ha legevakt på den måten? Det skjer jo åpenbart ikke dramatiske og akutte hendelser hele tiden. Hvorfor er det så ille å gå med påslått telefon og radio og få vaktgodtgjørelse mens man lever livet sitt som vanlig?

Hele livet må planlegges rundt legevakten, ikke bare for legen, men også for resten av familien 
Vaktradioen blir fort tung å ha i lomma. Hele livet må planlegges rundt legevakten, ikke bare for legen, men også for resten av familien. Alle aktiviteter som ikke kan forlates øyeblikkelig utgår - alarmen kan gå når som helst. Små barn kan ikke etterlates alene når mor eller far må rykke ut, så barnevakten må være klar. Man ender opp med å jogge rundt bilen for å få litt mosjon. Når man må kunne rykke ut i løpet av minutter, blir løpestrengen kort. Fjellturen utgår, skituren utgår, svømmeturen, fisketuren, klatreturen må vente. Etter en rask dusj er det raskt på med klærne igjen. Man kan ikke møte opp på en hjertestans i morgenkåpe. Legevaktradioen er med på fotballkamper, julespill og foreldremøter.

Fingrene krysses og volumet på radioen skrus så lavt som mulig for å ikke forstyrre andre. For tusenvis av fastleger i distrikt er det en logistisk utfordring å få plass til familieliv og fritidsaktiviteter.

Titt og ofte ringer vakttelefonen. Noen problemer kan løses over telefonen, men på de fleste vakter vurderer man flere pasienter, enten hjemme hos pasienten eller på legekontoret. Telefonen ringer også om natten. Ofte med reelle hastehenvendelser. Legevaktleger kler seg lynraskt i mørket, noen ganger med forbløffende resultat. Av og til ringer telefonen midt på natten med bagateller som kan vente. De minuttene det tar å avklare at det ikke krever øyeblikkelig hjelp, kan være nok til å vekke resten av familien. Én eller flere slike telefoner gjennom natten ødelegger søvnen.

Bedre balanse mellom arbeid og hvile er grunnlaget for et godt legeliv og er viktig for å sikre fremtiden for fastlegeordningen

Ifølge en rapport fra Nasjonalt kompetansesenter for legevaktmedisin er over halvparten av legevaktene i Norge interkommunale (5). Når det er flere som deler på vaktene, blir belastningen mindre på hver enkelt lege. I Nord-Gudbrandsdalen, der jeg jobber, har seks kommuner felles legevakt. Det har ført til en bedre hverdag for legene i regionen. Jeg har likevel rundt 650 timer legevakter i året. Det tilsvarer nesten 40 \% stilling i tillegg til full jobb som fastlege.

Det er ikke lenge siden sykehusleger hadde lignende arbeidsforhold. Den kampen ble vunnet, og selv om sykehusleger har lange og tunge vakter, er det lagt inn avspasering $\mathrm{i}$ turnusen som sikrer hvile (6). For fastleger i distrikt er det altfor lite hviletid. Det går på helsa løs. Legeforeningen har endelig satt ned foten mot rovdriften på fastlegene i distrikt. Streiken har som mål å begrense kommunenes mulighet til å pålegge fastlegene ubegrenset legevakt. Bedre balanse mellom arbeid og hvile er grunnlaget for et godt legeliv og er viktig for å sikre fremtiden for fastlegeordningen.

LITTERATUR:

1. Fastlegeordningen i krise - hva sier tallene. Rapport. Oslo: Menon Economics, 2018. https://www.legeforeningen.no/contentassets/1f3039425ea744adab5e11ac5706b85a/fastlegeordningen-i -krise-hva-sier-tallene-endelig-rapport.pdf Lest 28.10.2020.

2. Helsedirektoratet. Organisering av legevakt.

https://www.helsedirektoratet.no/veiledere/legevakt-og-legevaktsentral/organisering-av-legevakt\#ko mmunen-skal-tilby-legevaktordning-som-sikrer-befolkningens-behov-for-oyeblikkelig-hjelp-praktisk Lest 28.10.2020.

3. Arbeidsmiljøloven. https://lovdata.no/dokument/NL/lov/2005-o6-17-62 Lest 28.10.2020.

4. SFS2305 («Særavtalen»). Legeforeningen.no.

https://www.legeforeningen.no/jus-og-arbeidsliv/avtaler-for/leger-ansatt-i-kommunen/KS-leger-ansatti-kommunen/sentrale-avtaler/sfs-2305-Saeravtalen/ Lest 28.10.2020.

5. Nasjonalt kompetansesenter for legevaktmedisin. Legevaktorganisering i Norge. Rapport nr. 4/ 2019.

https://norceresearch.brage.unit.no/norceresearch-xmlui/bitstream/handle/11250/262599o/Rapport\%2 oNORCE\%2oHelse\%2C\%204-2019.pdf?sequence=1\&isAllowedy\#: :text-

De\%2oaller\%2ofleste\%2olegevaktsentralene\%2oer,\%2D102\%2olegevakter\%2oer\%2ointerkommunale. Lest 
28.10.2020.

6. Legeforeningen. Et avgjørende oppgjør i sykehusene.

https://www.legeforeningen.no/nyheter/2016/et-avgjorende-oppgjor-i-sykehusene. Lest 28.10.2020.

Publisert: 30. oktober 2020. Tidsskr Nor Legeforen. DOI: 10.4045/tidsskr.20.0872

Mottatt 29.10.2020, godkjent 29.10.2020.

(C) Tidsskrift for Den norske legeforening 2020. Lastet ned fra tidsskriftet.no 